\title{
Why Muslims like democracy yet have so little of it
}

\author{
Robbert Maseland • André van Hoorn
}

Received: 18 May 2009 / Accepted: 24 March 2010 / Published online: 8 April 2010

(C) The Author(s) 2010. This article is published with open access at Springerlink.com

\begin{abstract}
This paper explains the observed combination of relatively low levels of democracy and positive attitudes towards it in the Muslim world. It argues that this democracy paradox is understandable from the perspective of the principle of diminishing marginal utility: people value highly that of which they have little. This reasoning implies, however, that surveys like the World Values Surveys (WVS) elicit circumstance-driven marginal preferences rather than culturally determined attitudinal traits. Empirical evidence showing that individuals living in undemocratic societies have much more favorable inclinations towards democracy supports our argument.
\end{abstract}

Keywords Culture $\cdot$ Attitudes $\cdot$ Marginal preferences $\cdot$ Measurement $\cdot$ Outcomes

\section{Introduction}

In a recent illuminative paper in this journal, Rowley and Smith (2009) draw attention to what they call Islam's democracy paradox: the fact that Muslim-majority countries tend to be less democratic, while both individual Muslims and individuals in Muslim-majority countries value democracy more than other people do. Such a paradox has been observed by other authors as well (e.g., Bratton 2003; Hoffman 2004; Inglehart and Norris 2003; Jamal and Tessler 2008; Mogahed 2006; Rose 2002). To these authors, this gap between democratic attitudes and institutions in the Islamic world is puzzling. It has to be explained by other factors; gender equality (Inglehart and Norris 2003) and religious freedom (Rowley and Smith 2009) are suggested candidates.

This paper argues that looking for omitted variables to explain Islam's democracy puzzle is misguided. In fact, it claims there is no puzzle. We show, first of all, that the negative relation between democratic attitudes and actual levels of democracy is not unique to Muslim

R. Maseland (凶) · A. van Hoorn

Institute for International Economics, Business \& Management, University of Groningen, PO Box 800, 9700 AV, Groningen, The Netherlands

e-mail: R.K.J.Maseland@rug.nl

A. van Hoorn

e-mail: A.A.J.van.Hoorn@rug.nl 
countries. Secondly, we find that this paradoxical negative relation between attitudes and practices is of the same nature as other observed paradoxes in research of attitudinal traits, such as the finding by Bertrand and Mullainathan (2001) and Weil (2009) that those who value work the least tend to be most productive in terms of income (see also McCleary and Barro 2006). We argue that it can be understood in terms of the basic economic principle of diminishing marginal utility. If something is scarce, we value it more. Muslim-majority countries tend to be less democratic, so its inhabitants have a craving for more democracy. There is nothing paradoxical about this-it is basic microeconomics.

This argument fits an emerging trend in cross-cultural research criticizing values surveys measures for mistaking marginal preferences (the preference for increasing satiation of an objective given current levels of satiation) for attitudes (the preference for satiating the objective in general) (Maseland and van Hoorn 2009, 2010; Phelps 2006: 14-15 also raises this point). Whereas differences in attitudes may explain differences in outcomes such as levels of democracy, marginal preferences are driven by rather than drivers of differences in environments. Such arguments resonate with a broader literature that has come up in recent years propagating rational choice rather than cultural or theological explanations for the behavior of religious groups (e.g., Epstein and Gang 2007; Iannaccone and Berman 2006; Kurrild-Klitgaard et al. 2006). In the spirit of this literature, our argument indicates that instead of uncritically ascribing observed behavioral and ideational differences between groups to cultural or religious beliefs, they can be better understood in terms of rational responses to different circumstances. The so-called marginal preferences problem of values surveys implies that attitudinal indicators based on questionnaire items do not reflect cultural or religious differences, but simply diminishing marginal utility. Islam's democracy paradox serves to highlight this point.

The structure of this paper is as follows. In Sect. 2 we briefly consider the economics literature on religion and discuss the determinants of democracy and democratic attitudes, specifically the consistent observation of a Muslim democracy paradox. Section 3 provides a theoretical explanation for this paradox in terms of marginal preferences, culminating in hypotheses by which to test the validity of the marginal preferences argument. Section 4 presents our empirical analysis, showing that there is a consistent negative relation between democratic institutions and democratic attitudes as measured by questionnaire items from the World Values Survey (WVS). These results strongly support the marginal preferences argument. In Sect. 5, we conclude that the Muslim democracy paradox is part of this general negative relation between levels of democracy and measures of attitudes, and is attributable to the fact that the measures used elicit marginal preferences rather than attitudes.

\section{Islam and democracy: a supposed paradox}

\subsection{Religion in economics}

Interest among economists in religion and religious behavior has increased in recent years. Two main approaches can be distinguished. First, starting with Iannaccone's seminal contributions (1988, 1992a, 1992b), an expanding literature has developed that applies economic insights to religious behavior. The objective of this body of research is to explain religious behavior with the common tools of rational choice analysis. Some examples of this approach are the studies by Epstein and Gang (2007), Iannaccone and Berman (2006), and KurrildKlitgaard et al. (2006), all of which explain the occurrence of religious fundamentalism and terrorism in terms of a rational choice framework. This work shows that lack of freedom 
(Kurrild-Klitgaard et al. 2006), lack of effectively functioning states and markets (Iannaccone and Berman 2006), and the presence of competition between religious groups (Epstein and Gang 2007) are all conducive to religious extremism and militancy.

A second class of literature focuses on the consequences of religious beliefs and ideology for political and economic outcomes. In contrast to the rational choice approach to religion, this literature takes religious beliefs and ideology as exogenous inputs to political and economic behavior rather than seeing them as products of rational decision making. This approach has been given a lift by Huntington's famous clash of civilizations thesis (Huntington 1993, 1996), which boosted interest in the political-economic effects of religious values. Some research in this area is based on historical case studies (Kuran 2003, 2009), though most makes use of quantitative analyses relating political and economic outcomes to religious and cultural beliefs and values (e.g., Barro and McCleary 2003; McCleary and Barro 2006). As an early example of this trend, Glahe and Vorhies (1989) show that Judeo-Christian liberal values are conducive to economic development. As part of this literature, several studies have focused on the impact of the Islamic faith on democracy (Karatnycky 2002; Midlarsky 1998; Rowley and Smith 2009; see also Inglehart et al. 2002). This research has produced some supposedly paradoxical results.

\subsection{The democracy paradox of Islam}

The democracy paradox of Islam, according to Rowley and Smith (2009), is the fact that Muslim-majority countries tend to be significantly less democratic than other societies, although their citizens and, in fact, individual Muslims everywhere appear to entertain a more positive attitude towards democracy than others do.

The first part of this paradox is readily accepted. The determinants of democracy have been well researched, a primary driver being economic prosperity (Lipset 1959). Part of this relation between economic prosperity and the level of democracy runs through its effects on education and the size of the middle class (Shafiq 2009; Glaeser et al. 2007; Evans and Rose 2007; Hadenius 1992; Kamens 1988; Lipset 1959). However, with measures of education and middle class controlled for, income continues to have an independent effect as well (Barro 1999). Natural circumstances such as country size and insularity are further found to affect the prevalence of democracy (Anckar 2002; Barro 1999; Clague et al. 2001; Hadenius 1992), although the theoretical mechanism behind these relationships is rather obscure. In addition, income inequality, the urbanization rate, and ethnic heterogeneity have been argued to influence democracy. Statistically observable effects of these factors are rather weak, however (Barro 1999). On top of such general determinants of democracy, researchers have called attention to historical particularities such as colonial legacy (Anckar 2002; Clague et al. 2001; Huntington 1984; Weiner 1987), religious background, and cultural traditions (Clague et al. 2001; Huntington 1993; Inglehart 1988). In particular, Islam consistently shows up as a significant, negative factor in many empirical studies (Barro 1999; Fish 2002; Karatnycky 2002; Midlarsky 1998; Rowley and Smith 2009; Ross 2001). Several explanations have been proposed to explain this empirical regularity. These range from the absence of separation of church and state in Islam (Huntington 1993, 1996; see also Minkenberg 2007), through gender inequality (Fish 2002; Inglehart and Norris 2003), to endowments of oil (Barro 1999; Ross 2001). As it turns out, material conditions such as the availability of oil and the associated inequality explain something, but do not take away the significantly negative relation between a Muslim background and democratic institutions (Barro 1999; Fish 2002; Rowley and Smith 2009). The answer thus seems to lie in beliefs and attitudes associated with Islam itself. 


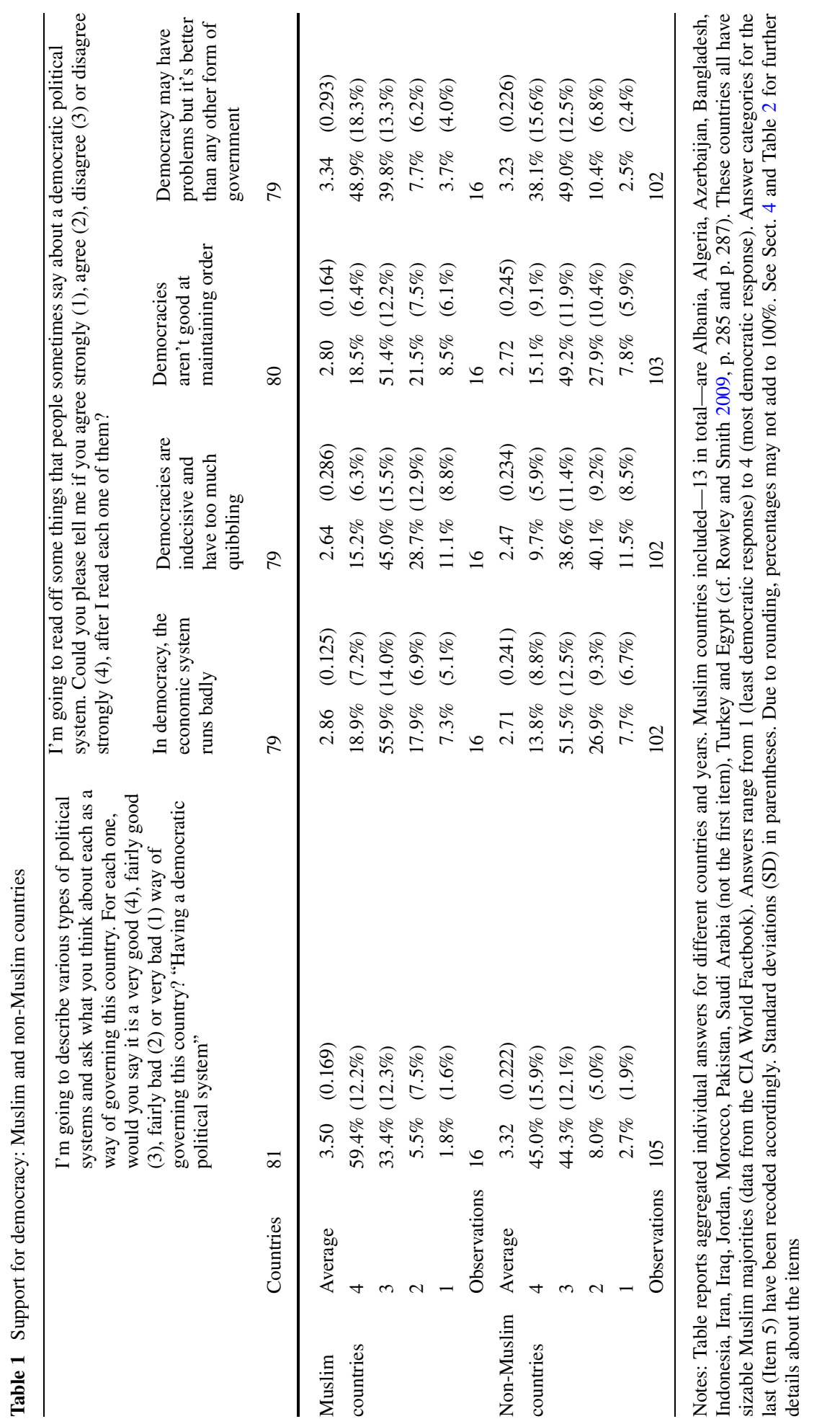


Yet, by now, a vast literature has emerged showing that Muslims tend to lack democratic institutions but not democratic inclinations (e.g., Bratton 2003; Hoffman 2004; Inglehart and Norris 2003; Jamal and Tessler 2008; Mogahed 2006; Rose 2002; Rowley and Smith 2009). Rather to the contrary, analysis of data from the World Values Survey (WVS) reveals that both individual Muslims and Muslim-majority countries have a relatively favorable perception of democracy (Rowley and Smith 2009). To show this, we repeat Rowley and Smith's (2009: 290-292) individual-level analysis of the association between Islam and democratic attitudes at the country level. Data on attitudes towards democracy also come from the WVS (European Values Study Group \& World Values Survey Association 2006) and Table 1 depicts the results for the five items on democracy included in the WVS. ${ }^{1}$

It appears that democracy has universal appeal with the percentages of people viewing democracy as something very good or fairly good being high both among Muslim and nonMuslim societies - the third item asking people whether they feel democracy is indecisive and has too much squabbling is an exception. The difference between Muslim countries and the rest of the world does not lie so much in the share of democratically inclined people but in how positive towards democracy people are. Whereas almost everyone seems to view democracy favorably to some extent, Table 1 clearly shows that people from Muslim countries are more prone to be very rather than fairly positive about democracy. The most comprehensive evidence comes from comparing the mean scores on the five democracy items. In most cases - the fourth item is an exception - the average attitude towards democracy is statistically significantly more positive in Muslim countries than it is other countries ( $p<0.10$ or better). It are these latter two findings that makes the relation between Islam and democracy appear paradoxical; "Muslims claim to like democracy, so why do they have so little?" (Rowley and Smith 2009: 273). ${ }^{2}$

Since they are tapping political attitudes in states where people may feel they are being endangered by expressing political opinions, we obviously need to take results of the polls in question with a healthy dose of caution (Kuran 1995; cf. Rowley and Smith 2009: 274). However, although a repressive environment may lead to preference falsification and thus cast doubt on the validity of surveys, it is not clear that this should have a systematic effect and thereby translate into a significantly more positive evaluation of democracy. In some cases-particularly where the authoritarian regime makes a point of cultivating a democratic façade - it might. It is just as likely, however, that repression causes people to understate their commitment to democracy. What is more, Rowley and Smith (2009) show that the positive relation between democratic attitudes and Islam exists not only at the country level but also at the level of individual Muslims. For these reasons, biases due to repressive environments likely do not cause the positive relation between Muslim identity and democratic attitudes. We need a different explanation.

\footnotetext{
${ }^{1}$ Rowley and Smith's (2009: 290-292) individual-level evidence based on the same items concerning individuals' attitude towards democracy can be found in their Tables 7 to 11. Their Table 12 (Rowley and Smith 2009: 293) gives some aggregate-level evidence of the positive relation between Islam and attitudes towards democracy. We discuss the five democracy items and our data in more detail in Sect. 4.

${ }^{2}$ This alleged paradox is robust to changes in the criterion that identifies countries as Muslim. Results are qualitatively unaffected when we replace Rowley and Smith's (2009: 285, 287) country classification with classifications based on Islam as the largest religion, Islam as religion of over $90 \%$ of the population, the percentage of Arabs, or predominantly Sunni Muslim populations (data from the CIA World Factbook; results available on request).
} 
Fig. 1 Choice between Materialist and Postmaterialist objectives

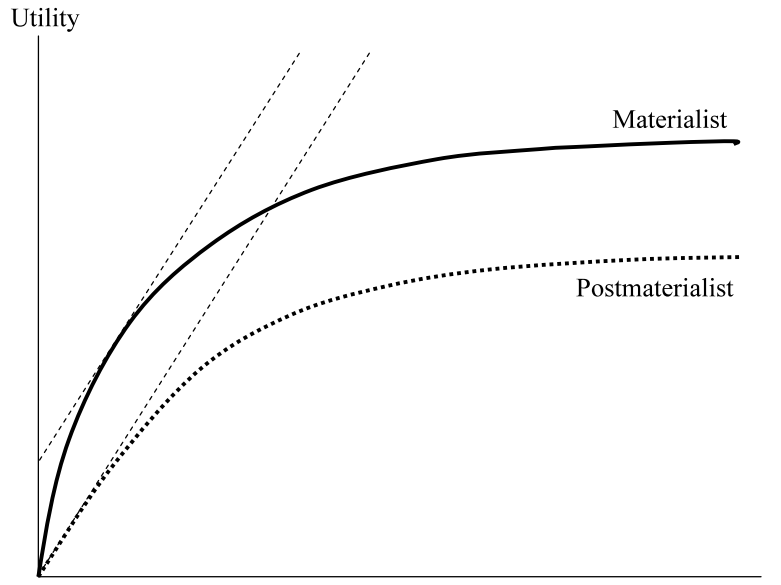

Level of satiation

\section{Explaining away the paradox: cultural attitudes and marginal preferences}

\subsection{Values versus marginal preferences}

Islam's democracy paradox fits in a longer list of paradoxes reported by researchers linking attitudes to outcomes. Measures of attitudes and values produced by survey instruments are found to fluctuate heavily with changing circumstances rather than appearing to be stable indicators of deep-rooted inclinations (Clarke et al. 1999; Duch and Taylor 1993). What is more, they correlate negatively with outcomes in many different areas. Bertrand and Mullainathan (2001), for example, find that individuals who value leisure more highly, work to earn larger incomes on average. Weil (2009) similarly reports that per-capita income levels are lower in societies attaching more importance to work relative to leisure. In an effort to investigate the relation between the value attached to objectives and outcomes more systematically, House et al. (2004) conducted a vast research project covering 62 societies. To their surprise, they find strong evidence that the value attached to objectives and the degree to which these objectives are satiated in a society are negatively correlated. Finally, throughout his work, Ronald Inglehart (1997) has consistently shown that those societies that attach the most value to materialist objectives, which concern material needs such as security, shelter and sustenance, are poorer than societies that care relatively less about material goals and favor postmaterialist objectives such as autonomy and self-expression instead.

The latter, of course, is not usually regarded a paradox. On the contrary, Inglehart (1997) has a perfectly plausible explanation for the value change he observes when societies grow richer. The richer a society becomes, the less importance people attach to growing richer still. Wealth, like most other objectives, faces diminishing marginal utility (see also Inglehart 1987, 1990). To show how this principle works, Fig. 1 illustrates a choice between materialist and postmaterialist objectives.

In this figure, the solid line depicts utility experienced by society as a result of satiating materialist objectives. The dotted line depicts utility derived from satiation of postmaterialist goals. The fact that the solid line lies above the dotted line indicates that society overall attaches more value to materialist than to postmaterialist goals. When faced with the choice of what to stress, society will therefore initially express a strong bias towards materialist objectives. Satiating material objectives renders more utility than satiating postmaterialist 
objectives. However, the declining slope of the function implies that the more materialist objectives become satiated, the less additional utility any more satiation delivers. The utility gained by extra materialist satiation relative to extra postmaterialist satiation thus falls. At some point, more material wealth becomes less attractive than satiating postmaterialist objectives. Society reaches this point when the slope of the solid line equals the slope of the dotted line in the origin; from there on, it will start favoring postmaterialism.

It is important to note that this eventual preference for postmaterialism in general is independent of the fact that, overall, society values materialism more. Society would still choose materialism over postmaterialism any time when satiation levels were equal. In other words, the attitude towards materialism has not changed; it is only the attitude towards more materialism on top of the current endowment that has changed. This distinction is important, because only the first corresponds to what the literature identifies as cultural values or attitudes (e.g., Hofstede 1980; House et al. 2004; Inglehart 1990, 1997), and only the first can function as an autonomous factor in determining behavior and outcomes. The latter, which we may dub the marginal preference for materialism, is determined by outcomes rather than determining them.

From a comparative point of view, the interpretation of survey scores as marginal preferences implies that societies, which emphasize postmaterialist objectives the most, are precisely those that have the highest satiation of materialist relative to postmaterialist objectives. This negative relation may seem paradoxical if one expects attitudes to be explanatory variables determining outcomes. However, if one views attitudes measured in surveys as responses to outcomes rather than as causes of them, a negative relation is exactly what one would expect.

\subsection{The diminishing marginal utility of democracy}

Can the principle of diminishing marginal utility, which Inglehart (1990) argues is the driving force behind the famous value shift in industrial societies, explain the other paradoxes in the study of proclaimed values and outcomes? The answer seems to be yes. The finding that those with a strong work ethic do not tend to generate much income (Bertrand and Mullainathan 2001; Weil 2009), suddenly makes sense if one interprets the survey score as marginal preference. Those who are working long hours earning a high income or in high-income jobs are likely to favor some leisure above more work, whereas those who are in low-income or part-time jobs are likely to have enough of leisure, preferring some work now. Similarly, the fact that respondents in Muslim-majority countries tend to favor democracy more, while having less of it, is also understandable. If their survey scores depict marginal preferences rather than an underlying cultural attitude, Muslims' sympathy for democracy simply reflects their relative deprivation of it; other people would be similarly enthusiastic about democracy were they to live in the kind of repressive environments that characterize many Islamic countries.

From this perspective the paradox observed in studies like that of Rowley and Smith (2009) needs no explanation. It simply does not exist. Countries with relatively low levels of democracy are likely to favor democracy more strongly because people value that which is scarce. To see a paradox in this is a consequence of a misinterpretation of WVS items as eliciting cultural attitudes where in actuality they capture marginal preferences. ${ }^{3}$

\footnotetext{
${ }^{3}$ It should be noted that even if the WVS items in question elicit marginal preferences, this by no means automatically holds for all WVS items. Indeed, many WVS items tap beliefs and perceptions of actual situations rather than attitudes and preferences. These are not sensitive to the marginal preferences problem; a person's belief in God is likely to increase only when the actual presence of God in his life increases.
} 


\subsection{Hypotheses}

It is possible to test whether the marginal-preferences problem plaguing attitudinal data accounts for the paradoxical relation between Islam and democracy by looking at the relation between the WVS items measuring democratic attitudes and democratic institutions in general. If the WVS items elicit cultural attitudes, as they have been designed to do, we expect a positive relation between sympathy for democracy and democratic institutions. In that case, the paradox remains; the question is why Muslim-majority countries' institutions do not evolve in line with their populations' preferences.

If, on the other hand, the WVS items elicit marginal preferences, we expect a negative correlation between the level of democracy and democratic attitudes as measured by the WVS items. The finding that Muslim-majority countries combine a relatively strong preference for democracy with little actual democracy is in that case just part of the general negative relation between marginal preferences and circumstances; the more one has of something, the less one desires increments to it.

At the same time, prosperity and education likely foster a more favorable outlook on democracy. This holds independent of the question whether survey measures elicit cultural attitudes or marginal preferences, although the mechanism differs between the two constructs. In the case of cultural attitudes, we expect the effect of gross domestic product (GDP) and education to run primarily through factors such as literacy and the size of a critical middle class, changing the mindset of people. In the case of marginal preferences, we also expect an effect of GDP and education, but here the mechanism is that satiation of these rival objectives makes democracy more important to people by default-rather like satiating materialist objectives makes people more postmaterialist (Inglehart 1987, 1990, 1997). In line with Robert Barro's view of democracy as a sort of luxury good (Barro 1996: 24), the relative deprivation of democracy is larger in societies where other pressing needs have been met.

Regardless of the mechanism involved, we therefore expect a positive effect of income and education on attitudes towards democracy. Any relation between democratic attitudes and levels of democracy should subsequently be seen as conditional on education and individual and country per-capita income. We have the following two competing hypotheses:

Hypothesis 1a: If the WVS items used to measure democratic attitudes elicit cultural attitudes, we expect a positive relation between attitudes measured by these items and actual levels of democracy, other factors controlled for.

Hypothesis 1b: If the WVS items used to measure democratic attitudes elicit marginal preferences, we expect a negative relation between attitudes measured by these items and actual levels of democracy, other factors controlled for.

We test these hypotheses in the next section where we combine individual-level data on professed attitudes towards democracy with data on existing levels of democracy in the respondents' countries, and include variables concerning individuals' socio-demographic characteristics and other features of their societies as controls, particularly individuals' level of education and GDP per capita.

\section{Empirical analysis}

\subsection{Data}

Data on our dependent variables come from the World Values Survey or WVS (European Values Study Group \& World Values Survey Association 2006). The WVS has grown out 
of the European Values Survey (EVS), which in the period 1981-1984 surveyed respondents from a number of European countries. Since then, it has evolved into a global project covering 84 societies, spanning some $80 \%$ of world population. Individual responses for all waves (1: 1981-1984, 2: 1989-1993, 3: 1994-1999, and 4: 1999-2004), almost 270,000 individuals in total, are now contained in a publicly available dataset. For our research, it is especially important to note that in the design and conduct of the WVS, care is taken to minimize the risk of potential distortions caused by repressive environments (see our discussion on preference falsification in section two). Survey questions are largely identical between countries - no compromises were made in politically repressive regimes-and interviewers are instructed to stress the confidentiality of respondents' answers. Interviews are conducted in isolation. In strongly male-dominated societies, women are interviewed by female interviewers. The websites of the WVS and the EVS, http://www.worldvaluessurvey.org and http://www.europeanvalues.nl, give further information concerning the items included in the survey and the way country surveys are conducted.

The WVS dataset contains several items concerning individuals' attitudes towards democracy. Following Rowley and Smith (2009) we identify five of these (cf. Table 1). The first item, Item 1, asks individuals how they feel about different systems for governing their country, including democracy: I'm going to describe various types of political systems and ask what you think about each as a way of governing this country. For each one, would you say it is a very good (4), fairly good (3), fairly bad (2) or very bad (1) way of governing this country? The other four items asks respondents what they think about certain features of democracy as a political system: I'm going to read off some things that people sometimes say about a democratic political system. Could you please tell me if you agree strongly (1), agree (2), disagree (3) or disagree strongly (4), after I read each one of them? The specific items read as follows: In democracy, the economic system runs badly (Item 2); Democracies are indecisive and have too much quibbling (Item 3); Democracies aren't good at maintaining order (Item 4); and Democracy may have problems but it's better than any other form of government (Item 5). We recode answers to these variables-specifically for the last item-so that a score of 1 corresponds to the least democratic response and 4 to the most democratic response with 2 and 3 in between (again see Table 1).

Next to data on democratic attitudes, we further rely on the WVS dataset for individuallevel control variables. Our aim is to investigate whether a country's level of democracy has a negative effect on the value its citizens attach to democracy, and we do so with potential individual determinants of democratic attitude controlled for. These are Employment status (Full-time, Part-time, Self-employed, Retired, Housewife, Student, Unemployed, or Other), Income scale (1-10), Education (Inadequately completed elementary education, Completed (compulsory) elementary education, Incomplete secondary school: technical/vocational type, Complete secondary school: technical/vocational type, Incomplete secondary: university-preparatory type, Complete secondary: university-preparatory type, Some university without degree, or University with degree), Sex, and Age. Table 2 gives descriptive statistics for our five democracy items and selected individual-level variables.

We supplement the WVS data on attitudes towards democracy and socio-demographics with country (and year) data on democracy and per-capita GDP. The source of the democracy data is the Polity IV Project. This project measures the democratic quality of governing institutions for 163 countries over the period 1800-2008. We use its revised polity measure (the so-called polity 2 measure) of democracy, which has been specifically developed for use in time-series analysis. We match the polity measure of democracy and our individual measures of democratic attitudes both to countries and years of the WVS data. Scores on the polity measure of democracy from the Polity IV Project range from 
Table 2 Descriptive statistics for selected variables

\begin{tabular}{llll}
\hline Variable & Mean & Individual observations & Standard deviation \\
\hline Dependents & & & \\
$\quad$ Item 1 & 3.34 & 155,879 & 0.733 \\
Item 2 & 2.73 & 141,203 & 0.803 \\
Item 3 & 2.48 & 143,891 & 0.833 \\
Item 4 & 2.72 & 144,305 & 0.820 \\
Item 5 & 3.24 & 146,381 & 0.743 \\
Independents & & & \\
Level 1 & & & 16.0 \\
Age & & & $50.0 \%$ \\
Sex (Male = 1) & 40.8 & 166,849 & $30.5 \%$ \\
Incomplete elementary education & $10.4 \%$ & 167,172 & $34.6 \%$ \\
University degree & $13.9 \%$ & 167,172 & \\
Level 2 & & & 5.50 \\
Polity IV & 5.66 & 152,364 & 7,054 \\
GDP [1990\$] & 8,541 & 165,058 & \\
\hline
\end{tabular}

Notes: Respondents with "don't know" or otherwise missing answers have been dropped. Data on selected independent variables covers only individuals and country observations for which scores on the dependents, Item $1-5$, are available

-10 (lowest score possible) to +10 (highest score possible). The Polity IV website, http://www.systemicpeace.org/polity/polity4.htm, gives a detailed description of the polity measure of democracy and access to a downloadable data file.

Our GDP data comes from The Conference Board \& Groningen Growth and Development Centre (2008) and we again make an exact match between countries and years available from this dataset and our WVS data. Levels of GDP per capita range from about $\$ 600$ to almost $\$ 34,000$ (1990 PPPs). The website of the Conference Board, http://www.conference-board.org/economics/database.cfm, has further information and an Excel file available for download. The bottom two rows of Table 2 give descriptive statistics for these two country-level variables.

\subsection{Methodology}

Our values data concern the attitudes towards democracy expressed by individuals living in certain countries and faced with a certain political environment. The nature of the data, and our theoretical argument predicting that contextual factors shape individuals' scores on questionnaire items aiming to elicit attitudes, call for a multilevel approach to testing our hypotheses. This way we avoid simply throwing together predictors at the individual and the contextual level, and treating them the same. In our case, we have individuals (level one) who are nested in countries (level two), and applying multilevel or hierarchical linear modeling (e.g., Gelman and Hill 2007) we are able to separate the individual and aggregate correlates of democratic attitudes and estimate them simultaneously. In addition, the multilevel technique allows for more efficient inference than is possible with either complete pooling or no pooling of the data. 
Given the nature of the data, with individuals nested in countries, it is further likely that clustering of observations causes a problem for traditional regression techniques. Individuals within countries are not independent observations so standard errors may be underestimated (e.g., Moulton 1990). Multilevel modeling takes such clustering into account.

For the formal empirical model we start with an individual $i$ (level one) living in country $j$ (level two). $D A_{i j}$ subsequently denotes the individual's attitude towards democracy (any of the five items). The dependent variable of interest is the level of democracy in a country measured by its score on the polity measure of democracy, $P D_{j}$. We also include $x_{i j}$, a set of individual-level control variables, and $G D P_{j}$, a country's level of per-capita GDP as a country-level control variable. This gives the following empirical models for levels one and two, separately and combined:

$$
\begin{array}{ll}
\text { Level 1: } & D A_{i j}=\beta_{0 j}+\beta_{1} x_{i j}+\varepsilon_{i j} \\
\text { Level 2: } & \beta_{0 j}=\gamma_{00}+\gamma_{01} P D_{j}+\gamma_{02} G D P_{j}+u_{0 j} \\
\text { Complete: } & D A_{i j}=\gamma_{00}+\gamma_{01} P D_{j}+\gamma_{02} G D P_{j}+\beta_{1} x_{i j}+\left(u_{0 j}+\varepsilon_{i j}\right) .
\end{array}
$$

The complete general model is a varying-intercepts (country fixed effects) model. We thus take into account any country-specific factors that may affect individuals' attitude towards democracy but are not controlled for by the aggregate-level variables that we include. The terms in parentheses constitute the random part of the model and the other terms the fixed part. The error terms in the random part capture the difference between a multilevel model and a traditional model: there is a "normal" residual error term $\left(\varepsilon_{i j}\right)$-familiar from classic regression analysis-but also an aggregate-level error term $\left(u_{0 j}\right)$. The model is estimated using maximum likelihood procedures.

\subsection{Results}

Table 3 depicts results for our baseline model with only individual-level (control) variables included. We estimated five empirical models (A1-A5) and included all of the individual variables. Hence, the models differ with respect to their dependent variable, i.e., the specific survey item used to measure democratic attitude. In line with the existing literature and our predictions, both personal income and education contribute to a more positive attitude towards democracy. In addition, we find that being employed generally has a positive effect, and that men tend to have stronger democratic attitudes than women do.

To test our hypotheses, we estimate the same five models, further including GDP per capita and the actual level of democracy as determinants of democratic attitudes (Models B1-B5). As Table 4 shows, there is a clear negative relation between the level of democracy and the attitude towards democracy for four out of five measures. For the other measure, Item 1 , we find no statistically significant relation between attitudes and levels of democracy. In line with our predictions, GDP per capita has a positive effect. Likelihood ratio tests further show that all B models provide a statistically significantly better fit than the A models $(p<0.05$ or better).

These findings lead us to accept Hypothesis $1 \mathrm{~b}$ (and reject Hypothesis 1a). Democratic attitudes do not seem to determine actual levels of democracy. Rather, they are a reaction to the level of democracy; if there is enough, people value it less. We note, however, that the results depicted in Table 4 may suffer from a multicollinearity problem as GDP per capita and level of democracy are likely correlated. Hence, to check the robustness of our findings we have also estimated the effect of the actual level of democracy on professed attitude 
Table 3 Baseline model with individual determinants of democratic attitude

\begin{tabular}{|c|c|c|c|c|c|}
\hline Variables & Model A1 & Model A2 & Model A3 & Model A4 & Model A5 \\
\hline Intercept & $\begin{array}{l}3.10^{* * *} \\
(0.033)\end{array}$ & $\begin{array}{l}2.52^{* * *} \\
(0.034)\end{array}$ & $\begin{array}{l}2.31^{* * *} \\
(0.037)\end{array}$ & $\begin{array}{l}2.54^{* * *} \\
(0.035)\end{array}$ & $\begin{array}{l}2.97 * * * \\
(0.036)\end{array}$ \\
\hline Part-time & $\begin{array}{l}-0.012 \\
(0.008)\end{array}$ & $\begin{array}{l}-0.024^{* *} \\
(0.009)\end{array}$ & $\begin{array}{l}-0.002 \\
(0.010)\end{array}$ & $\begin{array}{l}-0.001 \\
(0.010)\end{array}$ & $\begin{array}{l}0.002 \\
(0.009)\end{array}$ \\
\hline Self-employed & $\begin{array}{l}0.008 \\
(0.008)\end{array}$ & $\begin{array}{l}0.004 \\
(0.009)\end{array}$ & $\begin{array}{l}-(0.008 \\
(0.009)\end{array}$ & $\begin{array}{l}-0.008 \\
(0.009)\end{array}$ & $\begin{array}{l}0.013 \\
(0.008)\end{array}$ \\
\hline Retired & $\begin{array}{l}-0.024^{* * *} \\
(0.009)\end{array}$ & $\begin{array}{l}-0.052^{* * *} \\
(0.010)\end{array}$ & $\begin{array}{l}-0.067^{* * *} \\
(0.010)\end{array}$ & $\begin{array}{l}-0.045^{* * *} \\
(0.010)\end{array}$ & $\begin{array}{l}-0.027^{* * *} \\
(0.009)\end{array}$ \\
\hline Housewife & $\begin{array}{l}0.002 \\
(0.008)\end{array}$ & $\begin{array}{l}0.001 \\
(0.009)\end{array}$ & $\begin{array}{l}0.015 \\
(0.009)\end{array}$ & $\begin{array}{l}-0.006 \\
(0.009)\end{array}$ & $\begin{array}{l}0.006 \\
(0.008)\end{array}$ \\
\hline Student & $\begin{array}{l}0.049^{* * *} \\
(0.009)\end{array}$ & $\begin{array}{l}0.018 \\
(0.011)\end{array}$ & $\begin{array}{l}0.029^{* *} \\
(0.011)\end{array}$ & $\begin{array}{l}0.025^{* *} \\
(0.011)\end{array}$ & $\begin{array}{l}0.021^{* *} \\
(0.010)\end{array}$ \\
\hline Unemployed & $\begin{array}{l}-0.026^{* * *} \\
(0.008)\end{array}$ & $\begin{array}{l}-0.057^{* * *} \\
(0.009)\end{array}$ & $\begin{array}{l}-0.042^{* * *} \\
(0.009)\end{array}$ & $\begin{array}{l}-0.037^{* * *} \\
(0.009)\end{array}$ & $\begin{array}{l}-0.007 \\
(0.008)\end{array}$ \\
\hline Other employment status & $\begin{array}{l}-0.014 \\
(0.015)\end{array}$ & $\begin{array}{l}-0.016 \\
(0.017)\end{array}$ & $\begin{array}{l}-0.013 \\
(0.017)\end{array}$ & $\begin{array}{l}0.005 \\
(0.017)\end{array}$ & $\begin{array}{l}-0.003 \\
(0.015)\end{array}$ \\
\hline Income scale $(1-10)$ & $\begin{array}{l}0.010^{* * *} \\
(0.001)\end{array}$ & $\begin{array}{l}0.020^{* * *} \\
(0.001)\end{array}$ & $\begin{array}{l}0.017^{* * *} \\
(0.001)\end{array}$ & $\begin{array}{l}0.016^{* * *} \\
(0.001)\end{array}$ & $\begin{array}{l}0.008^{* * *} \\
(0.001)\end{array}$ \\
\hline $\begin{array}{l}\text { Inadequately completed } \\
\text { elementary education }\end{array}$ & $\begin{array}{l}-0.003 \\
(0.009)\end{array}$ & $\begin{array}{l}-0.007 \\
(0.010)\end{array}$ & $\begin{array}{l}0.035^{* * *} \\
(0.011)\end{array}$ & $\begin{array}{l}0.015 \\
(0.011)\end{array}$ & $\begin{array}{l}0.003 \\
(0.009)\end{array}$ \\
\hline $\begin{array}{l}\text { Incomplete secondary: } \\
\text { technical/vocational }\end{array}$ & $\begin{array}{l}-0.005 \\
(0.009)\end{array}$ & $\begin{array}{l}-0.023^{* *} \\
(0.010)\end{array}$ & $\begin{array}{l}-0.019^{*} \\
(0.010)\end{array}$ & $\begin{array}{l}-0.001 \\
(0.010)\end{array}$ & $\begin{array}{l}0.005 \\
(0.009)\end{array}$ \\
\hline $\begin{array}{l}\text { Complete secondary: } \\
\text { technical/vocational }\end{array}$ & $\begin{array}{l}0.070^{* * *} \\
(0.008)\end{array}$ & $\begin{array}{l}0.053^{* * *} \\
(0.009)\end{array}$ & $\begin{array}{l}0.034^{* * *} \\
(0.009)\end{array}$ & $\begin{array}{l}0.063^{* * *} \\
(0.009)\end{array}$ & $\begin{array}{l}0.054^{* * *} \\
(0.008)\end{array}$ \\
\hline $\begin{array}{l}\text { Incomplete secondary: } \\
\text { university-preparatory }\end{array}$ & $\begin{array}{l}0.068^{* * *} \\
(0.009)\end{array}$ & $\begin{array}{l}0.085^{* * *} \\
(0.010)\end{array}$ & $\begin{array}{l}0.064^{* * *} \\
(0.010)\end{array}$ & $\begin{array}{l}0.090^{* * *} \\
(0.010)\end{array}$ & $\begin{array}{l}0.083^{* * *} \\
(0.009)\end{array}$ \\
\hline $\begin{array}{l}\text { Complete secondary: } \\
\text { university-preparatory }\end{array}$ & $\begin{array}{l}0.125^{* * *} \\
(0.008)\end{array}$ & $\begin{array}{l}0.103^{* * *} \\
(0.009)\end{array}$ & $\begin{array}{l}0.095^{* * *} \\
(0.009)\end{array}$ & $\begin{array}{l}0.121^{* * *} \\
(0.009)\end{array}$ & $\begin{array}{l}0.105^{* * *} \\
(0.008)\end{array}$ \\
\hline Some university without degree & $\begin{array}{l}0.188^{* * *} \\
(0.010)\end{array}$ & $\begin{array}{l}0.188^{* * *} \\
(0.011)\end{array}$ & $\begin{array}{l}0.153^{* * *} \\
(0.011)\end{array}$ & $\begin{array}{l}0.208^{* * *} \\
(0.011)\end{array}$ & $\begin{array}{l}0.176^{* * *} \\
(0.010)\end{array}$ \\
\hline University with degree & $\begin{array}{l}0.233^{* * *} \\
(0.008)\end{array}$ & $\begin{array}{l}0.244^{* * *} \\
(0.009)\end{array}$ & $\begin{array}{l}0.219^{* * *} \\
(0.010)\end{array}$ & $\begin{array}{l}0.250^{* * *} \\
(0.010)\end{array}$ & $\begin{array}{l}0.206^{* * *} \\
(0.009)\end{array}$ \\
\hline Sex $($ Male $=1)$ & $\begin{array}{l}0.048^{* * *} \\
(0.004)\end{array}$ & $\begin{array}{l}0.060^{* * *} \\
(0.005)\end{array}$ & $\begin{array}{l}0.019^{* * *} \\
(0.005)\end{array}$ & $\begin{array}{l}0.033^{* * *} \\
(0.005)\end{array}$ & $\begin{array}{l}0.027^{* * *} \\
(0.005)\end{array}$ \\
\hline Age [/100] & $\begin{array}{l}0.251^{* * *} \\
(0.079)\end{array}$ & $\begin{array}{l}0.018 \\
(0.091)\end{array}$ & $\begin{array}{l}0.150 \\
(0.093)\end{array}$ & $\begin{array}{l}0.123 \\
(0.093)\end{array}$ & $\begin{array}{l}0.378^{* * *} \\
(0.083)\end{array}$ \\
\hline $\operatorname{Age}^{2}[/ 10,000]$ & $\begin{array}{c}-0.048 \\
(0.089)\end{array}$ & $\begin{array}{l}0.024 \\
(0.102)\end{array}$ & $\begin{array}{l}-0.207^{* *} \\
(0.104)\end{array}$ & $\begin{array}{l}-0.240^{* *} \\
(0.104)\end{array}$ & $\begin{array}{c}-0.122 \\
(0.093)\end{array}$ \\
\hline Countries & 69 & 68 & 68 & 68 & 68 \\
\hline Level-2 observations & 101 & 98 & 98 & 98 & 98 \\
\hline Individual observations & 117,565 & 106,031 & 107,824 & 107,240 & 109,335 \\
\hline -2Loglikelihood & $247,442.9$ & $242,503.9$ & $254,248.1$ & $249,992.7$ & $234,004.7$ \\
\hline
\end{tabular}

Notes: See Table 2. Standard errors in parentheses. ${ }^{*},{ }^{* *}$ and ${ }^{* * *}$ denotes significance at the $0.1,0.05$ and 0.01 level respectively. Base category is a full-time employed woman with completed (compulsory) elementary education. All models have varying intercepts 
Table 4 Multilevel results of the relation between level of democracy and democratic attitude

\begin{tabular}{llllll}
\hline Variables & Model B1 & Model B2 & Model B3 & Model B4 & Model B5 \\
\hline Intercept & $3.03^{* * *}$ & $2.44^{* * *}$ & $2.20^{* * *}$ & $2.42^{* * *}$ & $3.16^{* * *}$ \\
& $(0.043)$ & $(0.041)$ & $(0.050)$ & $(0.043)$ & $(0.065)$ \\
Polity & -0.001 & $-0.022^{* * *}$ & $-0.022^{* * *}$ & $-0.013^{* * *}$ & $-0.059^{* * *}$ \\
& $(0.001)$ & $(0.002)$ & $(0.002)$ & $(0.002)$ & $(0.002)$ \\
GDP & $0.078^{* * *}$ & $0.217^{* * *}$ & $0.249^{* * *}$ & $0.205^{* * *}$ & $0.146^{* * *}$ \\
& $(0.029)$ & $(0.029)$ & $(0.035)$ & $(0.030)$ & $(0.039)$ \\
\hline Individual controls & Yes & Yes & Yes & Yes & Yes \\
\hline -2Loglikelihood & $247,435.8$ & $242,352.7$ & $254,112.2$ & $249,925.1$ & $233,032.9$ \\
\hline
\end{tabular}

Notes: See Table 3. Individual controls are Employment status, Income scale (1-10), Sex, Education (dummies), Age and Age ${ }^{2}$

Table 5 Robustness: Effect of democracy without GDP

\begin{tabular}{llllll}
\hline Variables & Model C1 & Model C2 & Model C3 & Model C4 & Model C5 \\
\hline Intercept & $3.10^{* * *}$ & $2.62^{* * *}$ & $2.41^{* * *}$ & $2.59^{* * *}$ & $3.29^{* * *}$ \\
& $(0.034)$ & $(0.037)$ & $(0.038)$ & $(0.038)$ & $(0.061)$ \\
Polity & -0.000 & $-0.019^{* * *}$ & $-0.018^{* * *}$ & $-0.009^{* * *}$ & $-0.059^{* * *}$ \\
& $(0.001)$ & $(0.002)$ & $(0.002)$ & $(0.002)$ & $(0.002)$ \\
\hline Individual controls & Yes & Yes & Yes & Yes & Yes \\
\hline -2Loglikelihood & $247,442.9$ & $242,404.6$ & $254,163.1$ & $249,968.8$ & $233,044.9$ \\
\hline
\end{tabular}

Notes: See Table 4

towards democracy without controlling for levels of per-capita income (Models C1-C5). This is not our preferred model for theoretical reasons outlined above. Nevertheless, Table 5 shows our results to be robust: also with GDP excluded the actual level of democracy has a negative effect on attitudes towards democracy. ${ }^{4}$

Turning to implications for the Muslim democracy paradox, we find that no such paradox exists. Firstly, the paradox holds much more broadly: countries that have lower levels of democracy are consistently more democratically inclined-this negative correlation is not limited to Muslim countries. Secondly, measurement issues likely account for this observed negative correlation between attitudes towards democracy and actual democratic practice: such a negative attitude-practice correlation may result from the marginalpreferences problem - in which respondents are led by their current circumstances when asked how they feel about a certain state of affairs - known to affect attitudinal measures.

\footnotetext{
${ }^{4}$ As we would expect, Models C1-C5 provide better fits than Models A1-A5, but poorer fits than Models B1B5, as evidenced by their $-2 \operatorname{Loglikelihood~score.~Likelihood~ratio~tests~show~the~difference~to~be~statistically~}$ significant $(p<0.01)$. Model B1 is the exception.
} 


\section{Conclusion and discussion}

This paper has argued that there is no evidence of an Islamic democracy paradox. We show that the findings that Muslim countries are less democratic, whereas their inhabitants value democracy more, are not exceptional. A negative relation between democratic attitudes and democratic levels is a general phenomenon, not specific to Muslim countries. Neither is such a negative relation paradoxical. A relative lack of democracy makes people want more of it. This is the principle of diminishing marginal utility. That principle applies to marginal preferences, however, and not to people's underlying attitudes. It is only the preference for more democracy that increases when democratic institutions fade; the attitude towards democracy in general is not affected.

By arguing that marginal preferences lie behind the observed Islamic democracy paradox, we do not mean to claim that this is necessarily the only answer. As pointed out, survey instruments should be treated with caution when used in politically repressive contexts. What is more, survey instruments are prone to cultural differences in understanding of the concepts they deal with. The measures of democratic attitudes derived from the WVS deal only with how much people like democracy, while not everyone may understand the same thing by democracy. Based on the literature, one may hypothesize that Muslims tend towards different interpretations of democracy than others (Inglehart and Norris 2003; Mogahed 2006). Further research in this direction is needed.

The finding of an Islamic democracy paradox is another indication of the marginal preference problem in values surveys: questionnaire items on attitudes and related entities tend to elicit marginal preferences (the importance attached to an objective on top of its current level) rather much more so than durable attitudinal traits (the importance attached to an objective in general). Instead of taking attitudinal survey scores as exogenous inputs determining political-economic outcomes, these results show that interpreting them as rational reactions to different circumstances is more illuminative. Simply ascribing differences in professed attitudes or behavior to religion or cultural background does nothing to help us understand the rationality behind them. That is not to say that religious and cultural values do not matter. However, if we want to investigate cross-cultural differences in attitudes towards democracy or any other objective, this requires moving beyond values survey items towards other, more valid and more reliable measures.

Acknowledgements Part of this research was done while both authors were associated with the Radboud University Nijmegen (The Netherlands) and has been facilitated by the Institute for the Study of Labour (Germany). We thank the editor and two anonymous referees for their useful comments. The views expressed in this paper are those of the authors alone.

Open Access This article is distributed under the terms of the Creative Commons Attribution Noncommercial License which permits any noncommercial use, distribution, and reproduction in any medium, provided the original author(s) and source are credited.

\section{References}

Anckar, D. (2002). Why are small island states democracies? The Round Table, 365(1), 375-390.

Barro, R. J. (1996). Democracy and growth. Journal of Economic Growth, 1(1), 1-27.

Barro, R. J. (1999). Determinants of democracy. Journal of Political Economy, 107(6), S158-S183.

Barro, R. J., \& McCleary, R. M. (2003). Religion and economic growth across countries. American Sociological Review, 68(5), 760-781.

Bertrand, M., \& Mullainathan, S. (2001). Do people mean what they say? Implications for subjective survey data. American Economic Review, Papers and Proceedings, 91(2), 67-72. 
Bratton, M. (2003). Briefing: Islam, democracy, and public opinion in Africa. African Affairs, 102(408), 493-501.

Clague, C., Gleason, S., \& Knack, S. (2001). Determinants of lasting democracy in poor countries: Culture, development, and institutions. Annals of the American Academy of Political and Social. Science, 573(1), $16-41$.

Clarke, H. D., Kornberg, A., McIntyre, C., Bauer-Kaase, P., \& Kaase, M. (1999). The effect of economic priorities on the measurement of value change. American Political Science Review, 93(3), 637-647.

Duch, R. M., \& Taylor, M. A. (1993). Postmaterialism and the economic condition. American Journal of Political Science, 37(3), 747-779.

Epstein, G. S., \& Gang, I. N. (2007). Understanding the development of fundamentalism. Public Choice, 132(3-4), 257-271.

European Values Study Group \& World Values Survey Association (2006). European and World Values Surveys four-wave integrated data file, 1981-2004. Available from http://www.jdsurvey.net.

Evans, G., \& Rose, P. (2007). Support for democracy in Malawi: does schooling matter? World Development, 35(5), 904-919.

Fish, M. S. (2002). Islam and authoritarianism. World Politics, 55(1), 4-37.

Gelman, A., \& Hill, J. (2007). Data analysis using regression and multilevel/hierarchical models. Cambridge: Cambridge University Press.

Glaeser, E., Ponzetto, G., \& Shleifer, A. (2007). Why does democracy need education? Journal of Economic Growth, 12(2), 77-99.

Glahe, F., \& Vorhies, F. (1989). Religion, liberty and economic development: An empirical investigation. Public Choice, 62(3), 201-215.

Hadenius, A. (1992). Democracy and development. Cambridge: Cambridge University Press.

Hoffman, S. R. (2004). Islam and democracy. Comparative Political Studies, 37(6), 652-676.

Hofstede, G. (1980). Culture's consequences. Beverly Hills: Sage.

House, R. J., Hanges, P. J., Javidan, M., Dorfman, P. W., \& Gupta, V. (2004). Culture, leadership and organizations: The GLOBE study of 62 societies. Thousand Oaks: Sage.

Huntington, S. P. (1984). Will more countries be democratic? Political Science Quarterly, 99(2), $193-218$.

Huntington, S. P. (1993). The clash of civilizations. Foreign Affairs, 72(3), 22-50.

Huntington, S. P. (1996). The clash of civilizations and the remaking of the world order. New York: Simon \& Schuster.

Iannaccone, L. R. (1988). A formal model of church and sect. American Journal of Sociology, 94(S1), S241S268.

Iannaccone, L. R. (1992a). Sacrifice and stigma: Reducing free-riding in cults, communes, and other collectives. Journal of Political Economy, 100(2), 271-291.

Iannaccone, L. R. (1992b). Religious markets and the economics of religion. Social Compass, 39(1), 123131.

Iannaccone, L. R., \& Berman, E. (2006). Religious extremism: The good, the bad, and the deadly. Public Choice, 128(1-2), 109-129.

Inglehart, R. (1987). Value change in industrial societies. American Political Science Review, 81(4), 12891319 (Controversy with S. C. Flanagan).

Inglehart, R. (1988). The renaissance of political culture. American Political Science Review, 82(4), 12031230.

Inglehart, R. (1990). Culture shift in advanced industrial society. Princeton: Princeton University Press.

Inglehart, R. (1997). Modernization and postmodernization: Cultural, economic, and political change in 43 societies. Princeton: Princeton University Press.

Inglehart, R., \& Norris, P. (2003). The true clash of civilizations. Foreign Policy, 135, 63-70.

Inglehart, R., Norris, P., \& Welzel, C. (2002). Gender equality and democracy. Comparative Sociology, 1(34), 321-345.

Jamal, A., \& Tessler, M. (2008). The democracy barometers: attitudes in the Arab world. Journal of Democracy, 19(1), 97-110.

Kamens, D. (1988). Education and democracy: a comparative institutional analysis. Sociology and Education, 61(2), 114-127.

Karatnycky, A. (2002). Muslim countries and the democracy gap. Journal of Democracy, 13(1), 99-112.

Kuran, T. (1995). Private truths, public lies: the social consequences of preference falsification. Cambridge: Harvard University Press.

Kuran, T. (2003). The Islamic commercial crisis: institutional roots of economic underdevelopment in the Middle East. Journal of Economic History, 63(2), 414-447.

Kuran, T. (2009). Explaining the economic trajectories of civilizations: the systemic approach. Journal of Economic Behavior and Organization, 71(3), 593-605. 
Kurrild-Klitgaard, P., Justensen, M. K., \& Klemmensen, R. (2006). The political economy of freedom, democracy and transnational terrorism. Public Choice, 128(1), 289-315.

Lipset, S. M. (1959). Some social requisites of democracy: economic development and political legitimacy. American Political Science Review, 53(1), 69-105.

Maseland, R., \& van Hoorn, A. (2009). Explaining the negative correlation between values and practices: a note on the Hofstede-GLOBE debate. Journal of International Business Studies, 40(3), 527-532.

Maseland, R., \& van Hoorn, A. (2010, forthcoming). Values and marginal preferences in international Business. Journal of International Business Studies.

McCleary, R., \& Barro, R. (2006). Religion and economy. Journal of Economic Perspectives, 20(2), 49-72.

Midlarsky, M. I. (1998). Democracy and Islam: implications for civilizational conflict and the democratic peace. International Studies Quarterly, 42(3), 485-511.

Minkenberg, M. (2007). Democracy and religion: theoretical and empirical observations on the relationship between Christianity, Islam and liberal democracy. Journal of Ethnic and Migration Studies, 33(6), 887-909.

Mogahed, D. (2006). Special report: Muslim world, Islam and democracy. Washington DC: Gallup Poll Consulting University Press.

Moulton, B. R. (1990). An illustration of a pitfall in estimating the effects of aggregate variables on micro units. Review of Economics and Statistics, 72(2), 334-338.

Phelps, E. S. (2006). Economic culture and economic performance: What light is shed on the continent's problem? Paper presented at he Conference of CESifo and Center on Capitalism and Society on "Perspectives on the Performance of the Continent's Economies", Venice, 21-22 July 2006.

Rose, R. (2002). How Muslims view democracy. Journal of Democracy, 13(4), 102-111.

Ross, M. L. (2001). Does oil hinder democracy? World Politics, 53(3), 325-361.

Rowley, C. K., \& Smith, N. (2009). Islam's democracy paradox: Muslims claim to like democracy, so why do they have so little? Public Choice, 139(3), 273-299.

Shafiq, M. N. (2009). Do education and income affect support for democracy in Muslim countries? Evidence from the Pew Global Attitudes Project. Economics of Education Review, doi:10.1016/j.physletb.2003.10.071

The Conference Board \& Groningen Growth and Development Centre (2008). Total Economy Database. January 2008.

Weil, D. N. (2009). Economic growth (2nd ed.). Boston: Pearson/Wesley.

Weiner, M. (1987). Empirical democratic theory. In M. Weiner \& E. Özbudun (Eds.), Competitive elections in developing countries (pp. 3-34). Durham: Duke University Press. 